\title{
The Marginalization of Women in Pramoedya Ananta Toer's Novel: A Qualitative Descriptive Study of Sara Mills' Critical Discourse Analysis in Midah the Sweet Tooth of the Gold Novel, Larasati and the Beach Girl
}

\author{
Lenni Ashari ${ }^{1}$, Azis $^{1}$, Muhammad Saleh $^{1}$ \\ Email: lennyashari97@gmail.com \\ ${ }^{1}$ Language Education Study Program, Postgraduate Makassar State University, Indonesia \\ Received: November 15, 2021 \\ Received in Revised: December 24, \\ 2021 \\ Accepted: January 2, 2022
}

\begin{abstract}
This research is motivated by the many cases of marginalization found in women's themed novels written by one of the maestro of Indonesian literature, Pramoedya Ananta Toer. The novels written by Pramoedya Ananta Toer are known to often raise social problems that occurred at that time, including cases of marginalization of women. Midah Si Manis Bergigi Emas, Larasti and Gadis Pantai are several novels by Pramoedya Ananta Toer which tell the life journey of women as the main characters. The many forms of marginalization of rights experienced by women in these novels become something interesting for researchers. The purpose of this research is to uncover the representation of women's marginalization that occurs in the novels by Pramoedya Ananta Toer. The research method used is Sara Mills' critical discourse analysis which has been developed by Eryanto. Sara Mills' Critical Discourse Analysis emphasizes her study on the positioning of actors in the text or what is generally known as the subject-object position and the writer-reader position, however, the focus of this research is the subject-object position. The data collection technique used is literature study and documentation. The results of this study indicate that in the novel Midah Si Manis Bergigi Emas, Larasati, Gadis Pantai written by Pramoedya Ananta Toer, there are several forms of marginalization experienced by female characters in the novel. In addition to getting marginal treatment, the female character in the novel is also positioned as an object in the storytelling.
\end{abstract}

Keywords: Critical Discourse Analysis, Sara Mills, Marginalization of Women, Pramoedya
Ananta Toer's Novel

\section{Introduction}

Today, in the modern era when gender equality has been called for in almost all corners of the world, even to the deepest corners. At a time when women are free to choose the jobs they want and more and more women are occupying parliamentary seats to become influential figures, cases of gender injustice still occur. Without realizing it, cases of marginalization can have an unfavorable impact on society at large and women in general. The marginalization of rights and the impoverishment experienced by women make women's job opportunities narrower and cause women to experience other gender-biased treatments as a result of the impoverishment they experience.

If allowed to continue, marginalization can be the cause of the high rate of violence against women due to the lack of equality received by women and the stigma that grows from generation to generation about women and men. The marginalization of rights experienced by women makes the image of women as weak creatures stronger so that it provides an opportunity for certain elements to take advantage of this opportunity to do things arbitrarily to women, this is certainly not good and is not in accordance with the fifth principle of Pancasila, namely

Copyright @ 2022, Journal of Asian Multicultural Research for Social Sciences Study, Under the license CC BY-SA 4.0 
"justice". social services for all Indonesian people. Therefore, it is necessary to instill in the community the importance of gender equality and the negative impact of gender bias behavior, especially marginalization behavior.

The introduction of gender equality in society is important to avoid the occurrence of behaviors that are biased towards one gender in the future. Literary works are a medium for conveying ideas from poets through well-organized and meaningful ideas to the readers. Literary works generally raise social problems that often occur in society before being processed in such a way as to produce interesting dynamics (Sorokin \& Richard, 2017). Literary works can be said as a reflection of the social reality that occurs in society. Literary works describe people's lives, social conditions, culture and the history of life at that time (Hasebe-Ludt et al., 2009). This makes it easier for humans to look at the past or history of an area through literary works. However, a literary work is still a work of fiction so that it cannot be separated from the actual circumstances and conditions of society. Literary works are created from the reflection and imagination of the author. The fruits of reflection and imagination are then transformed into works that describe problems and everyday human life such as customs, history, politics, culture and the surrounding natural conditions. Literary works not only contain entertainment value but also many values that can be implemented in social life.

Literary works are used by the community as a means of communication. Communication itself functions as a means of conveying ideas, messages, ideas from various parties so that there is mutual influence between the communicating parties. Literary works that tell a lot about the marginalization experienced by women are novels. In addition to the complex and fairly long storyline, novels also generally involve more characters in the story, including female characters, than other literary works such as short stories, thus creating a large space for writers to talk about the marginalization of women in the story.

Axiologically, this study aims to reveal the marginal treatments experienced by female characters in the novel by Pramoedya Ananta Toer. This is based on the view that men are stronger, better than women, men can do more things than women. Pramoedya is a writer who often tells stories about social realities that he saw and experienced during his time. Pramoedya also tells a lot about women in his writings. Many of Pramoedya's writings openly tell of how marginalized women were at that time. Several of Pramoedya's novels that tell stories about women are Midah Si Manis with Golden Tooth, Larasati and Gadis Pantai which will be the sources of this research.

In an effort to present the representation of marginalization experienced by women in the novel by Pramoedya Ananta Toer, the researcher considers Sara Mills' Critical Discourse Analysis as the right choice in analyzing the novel to reveal the marginalization experienced by female characters in the novel. Critical Discourse Analysis Sara Mills model used in this study is a model that has been developed by Eriyanto (2009). The theory developed by Mills or what is commonly called feminist theory is present as an attempt to analyze power relations and the way women as individuals negotiate these matters. Mills emphasizes the way women are depicted in texts, both in the form of novels, pictures, photos and news (Mills in Eriyanto, 2009).

Mills focuses his analysis on the position of the actor shown in the text. The meaning of position in this theory is the way the actor is placed in the story, as the subject of the story or even placed in the position of the object of the story, which will later determine the structure of the text and the intent of the text as a whole. The position of the subject and object in the discourse representation contains a certain ideological charge. In this sense, women's positions often get stereotyped, marginalized, subordinated, violent and workloaded when displayed in the text. 
This position displays a certain limit from the point of view of storytelling. That is, all events in the text are told from the point of view of men.

\section{Methods}

This study uses a qualitative descriptive approach that aims to analyze data in the form of words, phrases, clauses and sentences that marginalize women found in Pramoedya Ananta Toer's novel. This study produces a description of the marginalization of women in the novel by Pramoedya Ananta Toer in terms of subject-object position based on Sara Mills' theory which has been developed by Eryanto.

The data collection process applied in this research is the referential method. The listening method is a way of obtaining data by listening and understanding carefully the use of language (Mahsun, 2007).

The text of the novel that will be observed and listened to in the printed version of the book as well as the electronic book and documented. The note-taking technique is an advanced technique after applying the listening method. The note-taking technique is done by writing or recording the data obtained. After being identified and marked in the novel, the data is then copied to the data card for in-depth and critical analysis. The library technique is carried out by means of researchers reading carefully and critically various literatures related to research and main data sources.

This study uses the role of the researcher as the main instrument. The data source used is a novel by Pramoedya Ananta Toer, while the data card as a research tool is used to record and classify the data that has been marked in the novel, the data is then copied to the data card for analysis. The stages of the data analysis process, after grouping the data, the data is then analyzed using critical discourse analysis techniques. Data analysis techniques are not bound and can be adapted to research needs and research problems. This research is based on a critical approach. Words and sentences in the novel are identified to find texts or sentences that represent victims of marginalization in the novel by Pramoedya Ananta Toer. The data in the form of words and sentences that represent acts of marginalization in the novel are then classified based on the position of the subject-object and the position of the writer-reader. The data, which have been grouped by type, were analyzed using Sara Mills' (2007) critical discourse analysis, to describe in detail the representation of marginalization in Pramoedya Ananta Toer's novel and how it is implemented in literary learning. At this stage, after the data has been analyzed, it is then interpreted and reaffirmed the forms of marginalization in the novel by Pramoedya Ananta Toer and then revealed the implications of these forms of marginalization in learning literature in schools.

\section{Results and Discussion}

In accordance with Mills' theory that has been developed by Eryanto, the aspect that is considered in this study is the position of the subject-object. The position of the subject-object referred to in this study is that the researcher identifies the actor who is the subject and object of the storytelling in the text. Based on the analysis that has been carried out by the researcher, some data are obtained showing that women are positioned as objects in storytelling which can cause women to experience marginalization that harms women, while the research findings are as follows:

\section{Prioritizing Boys Over Girls}

The presence of children in the household is something that parents dream of, however, the patriarchal culture that places men as strong figures, breadwinners and the highest decision makers has developed in society for generations, making many parents prefer the birth of a son. 
-boys than girls. In the novel Midah Si Manis Bergigi Emas, several sentences are found which indicate the strong desire of Midah's parents to have a son which ultimately results in the marginalization of rights experienced by Midah's daughter, as shown in the following data: (1) Until Midah was nine years old, the new child did not come either. And when Midah grew another year, the new child did not come. From then on, doubt crept in his heart. He even once said the words: Let me sacrifice everything, as long as I have another child - especially a boy. (D1.Mdh.11.PSO) (2) He regrets that words that deny God's destiny peek at him every time he has a conscience. Eventually the second child became the target of his anxiety. He prefers everything than what he has ever provided for Midah. (D2.Mdh.13.PSO) (3) Since the birth of a siad, he has not received attention from his father. Also not from mom. He performed various acts and songs, but all missed. A week later he had a fever. Father only came briefly to bring cake. And Mother was still lying on the bed near the siadik. (D3.Mdh.15.PSO)

Let me sacrifice everything, as long as I get another child-- especially a boy. Data (1) shows how much Hadji Abdul, Midah's father, wanted to have a son even though he already had a daughter who was so sweet. Referring to data (1), women seem to be inferior objects compared to men. The position of a son in a family is considered very important so that everything that a boy gets must be the best compared to a girl, starting from the material, even affection is always received more by boys than girls. This can be found in the data. (2) He prefers everything than what he has provided for Midah and data (3) Since the birth of the siadik, he has not received attention from his father. Also not from mom. The text shows the position of women is always under men even when with their own parents. Although this novel is a fictional story and was written decades ago, we can still find this kind of thing today and become a form of marginalization that can harm women.

\section{Elimination of women's work rights}

In addition to placing boys as actors whose presence is more important than girls, the marginalization of rights that is also experienced by women in Midah's novel is the dismissal or removal of work rights which is carried out unilaterally by men as shown in data (4) below: (4) You taught him? He shouted at the babu.

No, Hadji. Himself.

Haram! Haram! There must be someone to teach.

No one can answer Bang Hadji's accusations. And because his anger could not be contained anymore, everyone who worked in the kitchen was expelled that very day.

Data (4) shows that men have power over women. A male employer can fire a female worker without any consideration and it seems that the female does not have the power to defend herself so she is not fired. What Hadji Abdul has done in data (4) to the workers in his house shows that there is a marginalization of rights that can lead to poverty for women because they lose their livelihoods, while women are described as weak objects and cannot fight the injustices they experience.

\section{Discrimination due to physical and age}

The novel Midah Si Manis Bergigi Emas which shows the marginalization of rights that results in poverty for women is in the following data (5): (5) Your voice is so good. Pointing to the middle-aged woman with golden teeth, he continued: She is old, not attracting listeners anymore. His voice is not as good as yours. (D5.Mdh.32.PSO)

Women who are old enough are considered less attractive in terms of visuals and a decrease in productivity which is very influential in the world of work. This is supported by the presence of conditions that state the age limit and attractive appearance for job applicants in certain 
agencies. Indirectly this has put women in the second position under men, namely as additional breadwinners because women work shorter hours than men. The stereotype that develops in society that women after marriage and giving birth are no longer as attractive as before marriage and their work productivity has decreased, has led some agencies to prefer to hire men over women or even fire female employees after marriage. This is a form of real marginalization of women that we can still encounter today.

\section{Exploitation of women workers:}

The form of marginalization of women in the novel by Pramoedya Ananta Toer is also found in the novel entitled Larasati which is set in the war of independence as shown in the following data: (6) No admirers, no worshipers, no penny honorariums - Only eating hard rice and salted fish, and transporting on a slamming truck! (D10.Lst.26.PSO)

Data (6) shows that the woman in the story has experienced labor exploitation while her right to receive wages has not been fulfilled. This is a tangible manifestation of the marginalization of women which continues to this day. There are many women out there who work as laborers or other unskilled workers with wages that are not commensurate with the work that must be done, the gentle character that has been attached to women makes certain parties free to give small wages to women under the pretext of a job that is too expensive. The work done is not as hard as the work of men, so it is natural that the wages received are lower than men. Again, this places women in the second position after men and places women as weak and submissive objects.

\section{Placement of women as domestic workers}

The stigma that has developed from time to time that women are responsible for household tasks places women as actors who are only involved in the domestic sphere, as shown in the following data (7),(8): (7) "Where is mother, father?" "Where is the village woman's place if it's not in the kitchen?" (D21.GdsPnt.166.PSO) (8) And always facing the book a torturous question arose in his heart: am I only holding a rag, a chicken feather and a broom until I die? Canting, vegetables and plates used to eat Bendoro? And he also regrets not learning to read and write or the Koran (D22.GdsPnt.242243.PSO)

"Where is the village woman's place if it's not in the kitchen" data (21) clearly states that the position of women is in the kitchen at the back of a house. This becomes something interesting because the author indirectly tries to explain to the reader that the position of women is at the far back far from men who are always in the front. As a result of this positioning, the assumption that many people still hold today is that women do not need to go to high school because they will eventually return to the kitchen. This understanding limits the space for women to move forward and get better education and jobs.

Based on the subject-object position in Sara Mills' theory, an analysis has been carried out on three novels by Pramoedya Ananta Toer, namely Midah Si Manis Bergigi Mas, Larasati, and Gadis Pantai. So far, Mills has emphasized the way women are depicted in the text. The position of the actor is shown in the text, as the subject of the story or the object of the story that determines the structure and meaning of the text as a whole. The forms of marginalization of women based on subject-object positions found by researchers in this analysis are the prioritization of boys over girls, removal of women's work rights or dismissal, discrimination due to physical and age, exploitation of women workers and, placement of women as workers. domestic.

It is found that marginalization in Midah's novel is in the form of prioritizing boys over girls, elimination of work rights, exploitation of female workers and discrimination against women. 
In Larasati's novel, the most marginalization is found in the form of placing women as domestic workers and exploitation of women workers. The form of marginalization found in the novel Gadis Pantai is the placement of women as domestic workers. Women are described as weak, irrational, emotional, obedient, obedient creatures, and women are always identified with work in the domestic sphere. In contrast to men, who are always displayed in the form of leadership, strength and work in the public sphere, so that the decision-making process is in the hands of men and allows men to do things arbitrarily to women which can result in women experiencing impoverishment.

One of the factors that influence the gender-biased perspective of textbook writers is their social environment. Why is that? This is because the social environment is one of the factors that shape a person's perception or point of view of the surrounding environment and influences a person to feel or accept it. So that the text produced by the author cannot be separated from the social environment of the author of the textbook.

\section{Conclusion}

Marginalization cases against women are still found in many novels by Pramoedya Ananta Toer, even in each novel entitled Midah si Manis Bergigi Emas, Larasati and Gadis Pantai, there are several forms of marginalization experienced by female characters in the story. The forms of marginalization found in the three novels are seen from the subject-object position, namely $\mathrm{d}$. The writer places women as objects in the storytelling who cannot tell more about themselves and are always placed lower than men.

\section{References}

Eriyanto. (2001). Analisis wacana: pengantar analisis teks media. LKiS Yogyakarta.

Hasebe-Ludt, E., Chambers, C., \& Leggo, C. D. (2009). Life writing and literary métissage as an ethos for our times (Vol. 27). Peter Lang.

Mahsun, M. S. (2005). Metode penelitian bahasa: tahapan strategi, metode dan tekniknya. PT RajaGrafindo Persada.

Mills, S. (2007). Diskursus: sebuah piranti analisis dalam kajian ilmu sosial. Jakarta: Penerbit Qalam.

Sorokin, P., \& Richard, M. P. (2017). Social and cultural dynamics: a study of change in major systems of art, truth, ethics, law, and social relationships. Routledge.

Toer, P. A. (2005). Gadis Pantai. Jakarta: Lentera Dipantara.

Toer, P. A. (2009). Larasati. Jakarta: Lentera Dipantara.

Toer, P. A. (2010). Midah Si Manis Bergigi Emas. Jakarta: Lentera Dipantara. 